Saudi Journal of Biomedical Research

Abbreviated Key Title: Saudi J Biomed Res ISSN 2518-3214 (Print) |ISSN 2518-3222 (Online)

\title{
In Vitro Antioxidants, Antimicrobials and Biochemical Response of Methanol Leaf Extract of Eucalyptus camaldulensis following Sub- Acute Administration to Rats
}

Onukogu Stella Chiamaka ${ }^{*}$, Tsado Amos Ndarubu $^{2}$, Muhammad F. Mahmood ${ }^{1}$, Alawode Rahmatallah Adenike ${ }^{3}$, Suleiman Alfa ${ }^{4}$, Ojo Olufunmilola Praise ${ }^{5}$, Oshevire Rejoice-Eyihuri Musili ${ }^{1}$, Aishatu Mustapha ${ }^{5,6}$, Lawal Bashir $^{1}$

${ }^{1}$ Department of Biochemistry, Federal University of Technology Minna, P.M.B. 65, Nigeria

${ }^{2}$ Department of Biological Sciences, Niger State Polytechnic Zungeru, P.M.B 001, Zungeru, Niger State

${ }^{3}$ Forestry research institute of Nigeria-Southern Guinea Research Station, Mokwa, Niger State, Nigeria

${ }^{4}$ Department of Biological Sciences, Federal Polytechnic Bida, Nigeria

${ }^{5}$ Departments of Microbiology, Federal University of Technology Minna, P.M.B. 65, Nigeria

${ }^{6}$ Niger State Primary Health Care Development Agency Station: PHC Tunga Niger State Nigeria

DOI: $10.36348 /$ sjbr.2019.v04i11.007

| Received: 01.11.2019 | Accepted: 10.11.2019 | Published: 29.11.2019

*Corresponding author: Onukogu Stella Chiamaka

Abstract

Methanol leaf extract of Eucalyptus camaldulensis was investigated for phytochemical compositions, antioxidants, antimicrobial and safety profile. The antibacterial study was carried out using agar well diffusion method, while antioxidant activities were evaluated by 2, 2'- diphenyl-1- picrylhydrazyl (DPPH) and ferric reducing antioxidant power (FRAP) assays. A total of fifteen rats were divided into three groups (5 rats each) and were given $0,250 \mathrm{and} 500 \mathrm{mg} / \mathrm{kg}$ bwt of the extract orally for 28 days. Results revealed that tannins $(24.72 \pm 0.36 \mathrm{~g})$ is the most abundant phytochemicals followed by phenols $(6.01 \pm 0.89 \mathrm{mg} / \mathrm{g})$ while alkaloid $(0.19 \pm 0.67 \mathrm{mg} / \mathrm{g})$ was the least. Extract demonstrated antioxidant activities with $\mathrm{IC}_{50}$ of the $244.98 \pm 5.24 \mu \mathrm{g} / \mathrm{mL}$ and $462.755 \pm 6.98 \mu \mathrm{g} / \mathrm{mL}$ in DPPH and FRAP assays respectively. The extract inhibited the bacteria growth with minimum inhibitory concentrations (MIC) and minimal bactericidal concentrations (MBC) values ranged between 7.5-60 $\mu \mathrm{g} \mathrm{mL}^{-1}$ and $60-12 \mu \mathrm{g} \mathrm{mL}^{-1}$ respectively. The concentrations of albumins, bilirubins sodium, potassium, creatinine, serum transaminases and alkaline phosphatase (ALP) activities were not significantly $(\mathrm{p}>0.05)$ altered by the extract. Urea concentration was significantly $(\mathrm{p}<0.05)$ higher while proteins were lower in rats treated with $500 \mathrm{mg} / \mathrm{kg}$ bw of the extract. Methanol extract of E. camaldulensis could be considered as a cheap source of effective and safe herbal remedy with potential candidate for the development of a new drug.

Keywords: Phytochemicals, In vitro antioxidant, Eucalyptus camaldulensis, DPPH, Antibacterial.

Copyright @ 2019: This is an open-access article distributed under the terms of the Creative Commons Attribution license which permits unrestricted use, distribution, and reproduction in any medium for non-commercial use (NonCommercial, or CC-BY-NC) provided the original author and source are credited.

\section{INTRODUCTION}

Plants are free gifts of nature available at human disposal for various pharmacological uses. It has been used as a primary source of oral remedies for various ailments and diseases from a time immemorial [1]. The recent growth in knowledge of free radicals and reactive oxygen species (ROS) in biological systems is producing a medical revolution that promises a new age of health [2]. These reactive oxygen species play an important role in degenerative or pathological processes, such as aging, cancer, coronary heart disease, Alzheimer's disease, atherosclerosis, cataracts, and inflammation [3].

A number of studies have linked the antioxidants in natural products particularly, plants with reduction of chronic diseases and inhibition of pathogenic bacteria growth, which are often associated with the termination of free radical proliferation in biological systems [4-6]. Microbial infections have always been considered as a leading cause of morbidity and mortality in humans. The microbial resistance to the existence antibiotics is well known, so it is very important to search for alternative antimicrobial agents from natural source like plants or herbs to overcome this challenge [7].

Eucalyptus camaldulensis Dehnh, also called the river red gum, it is a large aromatic tree that is endemic in Australia [8]. It is the most important genera of Myrtaceae family commonly used in Traditional medicine for the treatment of sore throat, wounds, asthma, burns, fever, influenza, arthritis, malaria, and 
pharyngitis $[9,10]$. Pharmacologically, leaves of $E$. camaldulensis are well documented for cytotoxic [11], antimicrobial [12], insecticidal [13], antioxidant [8] and anti-dermatophytes [14] activities. Previous phytochemistry revealed that acylated pentacyclic triterpenoids [15], eucalyptanoic acid [16] and essential oils [17] are the major bioactive metabolite in $E$. camaldulensis. The aim of the current study was to evaluate the in vitro antimicrobial, antioxidants and safety evaluations of E. camaldulensis leaves' extract in rats

\section{MATERIAL AND METHODS \\ Sample preparation and extraction}

The fresh leaves of Eucalyptus camaldulensis were collected from Minna, Niger State. The leaf was destalked, washed with clean-water, dried at room temperature and finally grounded using a grinder mill and dried at room temperature. Extraction of plant materials was performed by weighing $50 \mathrm{~g}$ of the powdered plants and extracted by soxhlet extraction using $200 \mathrm{ml}$ of methanol.

\section{Phytochemical Analysis}

Evaluation of the extract for qualitative phytochemical compositions including saponins, tannins, glycoside, alkaloids, steroids and flavonoids were determined by the methods described by Harborne [18] and Sofowora [19]. The quantitative concentration of alkaloids in the extract was determined by the method described by Harborne [18], saponins contents as described by Chang et al. [16] flavonoids and phenols by methods described by Oloyed [14] while tannins contents was determined by the methods of AOAC [20].

\section{Assay for antibacterial activities}

Antibacterial activity of the extract was carried out using agar-well diffusion method as described by Gaherwal et al. [21]. Minimum inhibitory concentration (MIC) and minimum bactericidal concentration (MBC) were determined by tube dilution method for each of the test organism as described by Tsado et al. [22] in triplicates.

\section{Assay for Antioxidant activities}

DPPH radical scavenging activity of the plant extract at varying concentrations $(2.5-100 \mu \mathrm{g} / \mathrm{mL})$ was measured in vitro via the $2,2^{\prime}$ - diphenyl-1picrylhydrazyl (DPPH) assay as described by Tsado et al. [23], while Fe3+ ion reducing power of the sample was evaluated using varying extract concentrations $(2.5$ - $100 \mu \mathrm{g} / \mathrm{mL}$ ) according to the methods described previously $[53,54]$. The extract concentration providing $50 \%$ inhibition (IC50) was calculated from the plot of inhibition (\%) against extract concentration. Ascorbic acid at the same concentrations was used as the reference antioxidants.

\section{Toxicological Study}

Acute toxicity was carried out as described previously [24]. In the subacute toxicity animals (5 each) were dosed 0 (control), 250 and $500 \mathrm{mg} / \mathrm{kg}$ bwt of the extract orally for 28 days. Procedures described by Shittu et al. [15] and Yusuf et al. [26] were followed during blood sample collection and serum preparation for biochemical analysis. Serum activities of alkaline phosphatase (ALP), Aspartate transaminase (AST) and alanine transaminase (ALT) were determined as described previously [27]. The concentrations of serum total proteins [28], bilirubins, albumins [29], urea creatinine [30], sodium, potassium, and chloride [31] were determined using standard methods.

\section{STATISTICAL ANALYSIS}

Values were analyzed using statistical package for social science (SPSS) version 16 and presented as means \pm SE of the mean. Comparisons between different groups were carried out by one-way analysis of variance (ANOVA) followed by Duncan's Multiple Range Test (DMRT). The level of significance was set at $P<0.05$ [32].

\section{RESULTS \\ Phytochemical composition}

The qualitative analysis of phytochemicals revealed the presence of phenols, tannins, alkaloids, saponins, glycoside, terpenes, anthraquinone and flavonoids. Phlobatannins was absence (Table 1). Quantitatively, tannins $(24.72 \pm 0.36 \mathrm{~g})$ is the most abundant phytochemicals in methanol leaf extract of Eucalyptus camaldulensis, followed by phenols $(6.01 \pm 0.89 \mathrm{mg} / \mathrm{g})$ while alkaloid $(0.19 \pm 0.67 \mathrm{mg} / \mathrm{g})$ was the least abundant phytochemicals.

Table-1: Phytochemical composition of methanol leaf extract of Eucalyptus camaldulensis:

\begin{tabular}{|l|c|c|}
\hline Phytochemicals & Inferences & Quantity $(\mathbf{m g} / \mathbf{g})$ \\
\hline Phenol & + & $6.01 \pm 0.89^{\mathrm{d}}$ \\
\hline Flavonoids & + & $0.71 \pm 0.14^{\mathrm{b}}$ \\
\hline Tannins & + & $24.72 \pm 0.36^{\mathrm{e}}$ \\
\hline Saponins & + & $3.13 \pm 0.45^{\mathrm{c}}$ \\
\hline Alkaloids & + & $0.19 \pm 0.67^{\mathrm{a}}$ \\
\hline Cardiac glycosides & + & \\
\hline Anthraquinone & + & \\
\hline Steroids & + & \\
\hline Terpenes & + & \\
\hline Phlobatannins & - & \\
\hline
\end{tabular}

Data are Mean \pm SEM of triplicate determination

\section{Antioxidants activities}

Methanol extract of Eucalyptus calmaldulensis promoted an inhibition of DPPH radical with increasing concentrations (Fig. 1). The $\mathrm{IC}_{50}$ of the of the extract against DPPH radicals is $244.98 \pm 5.24 \mu \mathrm{g} / \mathrm{mL}$ as compared with $79.64 \pm 3.78 \mu \mathrm{g} / \mathrm{mL}$ recorded for the reference drug (Ascorbic Acid). The extract also exhibited FRAPS activities that increase with increase extract concentration (figure 2). The $\mathrm{IC}_{50}$ recorded for 
the extract in FRAP assay was $462.755 \pm 6.98 \mu \mathrm{g} / \mathrm{mL}$ as compared with $204.50 \pm 1.78 \mu \mathrm{g} / \mathrm{mL}$ recorded for reference drug (ascorbic Acid).

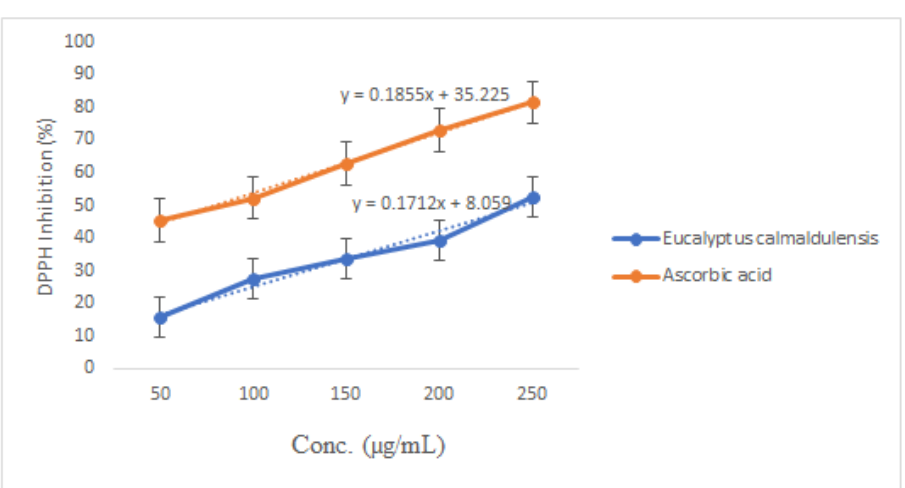

Fig-1: DPPH radical scavenging activities of methanol extract of Eucalyptus calmaldulensis. Values are mean \pm SEM of 3 determinations. IC $_{50}$ $=244.98 \pm 5.24 \mu \mathrm{g} / \mathrm{mL}$ (Eucalyptus calmaldulensis), $79.64 \pm 3.78 \mu \mathrm{g} / \mathrm{mL}$ (Ascorbic Acid).

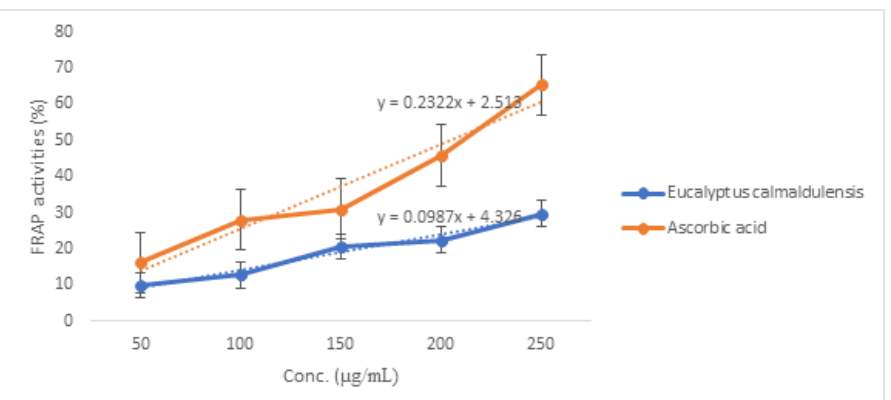

Fig-2: FRAP activity of leaf extracts of methanol extract of Eucalyptus calmaldulensis. Values are mean \pm SEM of 3 determinations. IC50 $=$ $462.755 \pm 6.98 \mu \mathrm{g} / \mathrm{mL}$ (Eucalyptus calmaldulensis), $204.50 \pm 1.78 \mu \mathrm{g} / \mathrm{mL}$ (Ascorbic Acid)

\section{Antimicrobial activities}

Methanol leaf extract of Eucalyptus camaldulensi inhibited the growth of Streptococcus pyoginase, Klebsiella pneumonae, Pseudomonas aeruginasa, Staphylococcus aureus and Bacillus subtilis in a dose dependent manner. The extract at 20 and $40 \mu \mathrm{g} / \mathrm{mL}$ were not active against Streptococcus pyoginase. The highest zone of inhibition (33.00 \pm 1.90 $\mu \mathrm{g} / \mathrm{mL}$ ) was recorded against Pseudomonas aeruginase while the least $(22.00 \pm 2.03 \mu \mathrm{g} / \mathrm{mL})$ was recorded against Streptococcus pyoginase (Table 2). Overall results showed that the extract of E. camaldulensis leaves had MIC values ranged between 7.5-60 $\mu \mathrm{g} \mathrm{mL}^{-1}$ and MBC values ranged between $60-12 \mu \mathrm{g} \mathrm{mL}^{-1}$ (Table 3).

Table-2: Zone of Inhibition of the organism caused by methanol leaf extract of Eucalyptus camaldulensi

\begin{tabular}{|l|l|l|l|l|l|}
\hline & \multicolumn{5}{|c|}{ Conc $(\boldsymbol{\mu g} / \mathbf{m L})$} \\
\hline Bacteria (Test organism) & 20 & 40 & 60 & 80 & 100 \\
\hline Streptococcus pyoginase & Nil & Nil & $13.00 \pm 0.59$ & $19.00 \pm 1.98$ & $22.00 \pm 2.03$ \\
\hline Klebsiella pneumonae & $18.00 \pm 1.93$ & $14.00 \pm 1.90$ & $17.00 \pm 1.09$ & $22.00 \pm 2.03$ & $30.00 \pm 2.89$ \\
\hline Pseudomonas aeruginase & $13.00 \pm 0.78$ & $14.00 \pm 0.97$ & $24.00 \pm 2.08$ & $28.00 \pm 2.89$ & $33.00 \pm 1.90$ \\
\hline Staphylococcus aureus & Nil & $21.00 \pm 2.89$ & $23.00 \pm 1.09$ & $24.00 \pm 1.98$ & $25.80 \pm 2.32$ \\
\hline Bacillus subtilis & $9.70 \pm 0.67$ & $12.20 \pm 0.98$ & $19.00 \pm 2.06$ & $21.00 \pm 1.90$ & $24.00 \pm 1.90$ \\
\hline
\end{tabular}

Data are Mean \pm SEM of triplicate determination

Table-3: Minimum inhibitory and minimum bacterialcidal concentrations of methanol leaf extract of Eucalyptus camaldulensi

\begin{tabular}{|l|l|l|}
\hline Bacteria (Test organism) & MIC $(\mu \mathrm{g} / \mathrm{mL})$ & MBC $(\mu \mathrm{g} / \mathrm{mL})$ \\
\hline Streptococcus pyoginase & 60 & 60 \\
\hline Klebsiella pneumonae & 7.5 & 30 \\
\hline Pseudomonas aeruginase & 30 & 60 \\
\hline Staphylococcus aureus & 60 & 120 \\
\hline Bacillus subtilis & 60 & 60 \\
\hline
\end{tabular}

\section{Biochemical Parameters}

The concentrations of albumins, bilirubins sodium, potassium, creatinine, serum aspartate transaminase, alanine transaminase and alkaline phosphatase (ALP) activities were not significantly $(\mathrm{p}<0.05)$ altered by treatment with 250 and $500 \mathrm{mg} / \mathrm{kg}$ 
bw E. camadulensis. However, serum concentration of urea were significantly $(\mathrm{p}<0.05)$ higher while proteins were lower in rats treated with $500 \mathrm{mg} / \mathrm{kg}$ bw $E$. camadulensis when compared with the normal control.
Chloride concentration was higher in rat's dosed 250 and $500 \mathrm{mg} / \mathrm{kg}$ bw E. camadulensis when compared with the control.

Table-4: Effect of methanol extract of $E$. camadulensis on biochemical parameters in rats

\begin{tabular}{|l|l|l|l|}
\hline & Control & $\mathbf{2 5 0} \mathbf{~ m g} / \mathbf{k g ~ b w}$ & $\mathbf{5 0 0} \mathbf{~ m g} / \mathbf{k g ~ b w}$ \\
\hline AST (U/L) & $56.23 \pm 2.09^{\mathrm{a}}$ & $59.89 \pm 4.32^{\mathrm{a}}$ & $55.08 \pm 3.23^{\mathrm{a}}$ \\
\hline ALT (U/L) & $72.93 \pm 3.21^{\mathrm{a}}$ & $74.09 \pm 5.89^{\mathrm{a}}$ & $79.89 \pm 3.94^{\mathrm{a}}$ \\
\hline ALP (U/L) & $156.34 \pm 5.43^{\mathrm{a}}$ & $162.93 \pm 4.32^{\mathrm{a}}$ & $158.34 \pm 7.93^{\mathrm{a}}$ \\
\hline Total proteins (mg/dL) & $52.88 \pm 1.23^{\mathrm{b}}$ & $54.21 \pm 2.34^{\mathrm{a}}$ & $31.90 \pm 2.90^{\mathrm{a}}$ \\
\hline Albumin (mg/dL) & $2.09 \pm 0.03^{\mathrm{a}}$ & $2.12 \pm 0.27^{\mathrm{a}}$ & $2.11 \pm 0.63^{\mathrm{a}}$ \\
\hline Bilirubin (mg/dL) & $1.69 \pm 0.22^{\mathrm{a}}$ & $1.59 \pm 0.21^{\mathrm{a}}$ & $1.55 \pm 0.14^{\mathrm{a}}$ \\
\hline Urea (mg/dL) & $123.23 \pm 3.24^{\mathrm{a}}$ & $126.09 \pm 3.21^{\mathrm{a}}$ & $171.89 \pm 4.34^{\mathrm{b}}$ \\
\hline Creatinine (mg/dL) & $3.78 \pm 0.78^{\mathrm{a}}$ & $3.89 \pm 0.24^{\mathrm{a}}$ & $3.18 \pm 0.13^{\mathrm{a}}$ \\
\hline Sodium (Meq/L) & $45.32 \pm 2.34^{\mathrm{a}}$ & $43.90 \pm 4.32^{\mathrm{a}}$ & $46.32 \pm 3.89^{\mathrm{a}}$ \\
\hline Potassium (Mmol/L) & $7.09 \pm 0.78^{\mathrm{a}}$ & $7.12 \pm 0.53^{\mathrm{a}}$ & $7.05 \pm 0.14^{\mathrm{a}}$ \\
\hline Chloride (Mmol/L) & $132.90 \pm 3.45^{\mathrm{a}}$ & $159.23 \pm 3.97^{\mathrm{b}}$ & $165.98 \pm 5.43^{\mathrm{b}}$ \\
\hline
\end{tabular}

Data are Mean \pm SEM of triplicate determination. Value followed by different superscript alphabet along the column were significantly different $(\mathrm{p}<0.05)$.

\section{DISCUSSION}

The present study revealed the presence of various important medicinal phytochemicals in methanol leaves extract of eucalyptus calmaldulensis. In line with the present study, Azzah and Ibtisam [10] also reported the presence of saponins, tannins, flavonoids, carbohydrate and protein compounds in leaves and bark extracts of E. camaldulensis [10].

Quantitatively, tannins $(24.72 \pm 0.36 \mathrm{~g})$ is the most abundant phytochemicals in methanol leaf extract of Eucalyptus camaldulensis, followed by phenols $(6.01 \pm 0.89 \mathrm{mg} / \mathrm{g})$ while alkaloid $(0.19 \pm 0.67 \mathrm{mg} / \mathrm{g})$ was the least abundant phytochemicals. Previous studies stated that phenolic compounds are responsible for antioxidants and antimicrobial activity of the plant extracts [33, 34, 35, 35]. Flavonoids are most diversified groups of phenolic compounds found in plant, it biological activity include, antioxidants antibacterial, anti-inflammatory, anti-allergic, protect against ulcers, vineses and antitumor effect [37]. Saponin has been reported to have anti-inflamatory, cardiac depressant and hyper-cholesterolemic effect [38]. Alkaloids have been found to have microbiocidal effect, antihypertensive antifungal, anti-inflammatory and antifibrogenic effect [39]. Previous researchers have also demonstrated the antimicrobial and antioxidant effect of glycosides [40]. Thus, the phytochemical constituents indicate that the methanol extract of eucalyptus calmaldulensis could yield a drug of pharmaceutical significance. However, the absence of phlobatannins agrees with the earlier study which reported that not all phytochemicals are present in medicinal plant and those present differs with the solvent used in the extraction process [14]

The antimicrobial activities of methanol leaf extract of Eucalyptus calmaldulensis showed that the extracts had good antimicrobial activity against the test organism. This consistent with the prior studies [42, 34,
43, 44], that proved E. camaldulensis extracts possess the ability to inhibit the growth of Gram-positive and Gram-negative bacteria. The ability of the methanol leaf extract of Eucalyptus calmaldulensis to inhibit the growth of Gram-positive and Gram-negative bacteria explains why it is used in folk medicine for the treatment of sore throat, wounds, asthma, burns, fever, influenza, arthritis, malaria, and pharyngitis [9, 10]. Increase in the concentration of the extract results in corresponding increase in the zones of inhibitions. This linear relationship between extract concentrations and zones of inhibition could be that the extract was able to diffuse into the inoculated nutrient agar [23, 45].

Minimum inhibitory concentration (MIC) is the lowest concentration of an extract that inhibit the visible growth of the test organism after 24hrs incubation [22]. In the present study MIC was measured based on turbidity or visible growth show by the organism. That the extract of E. camaldulensis leaves had MIC values ranged between 7.5-60 $\mu \mathrm{g} \mathrm{mL} \mathrm{m}^{-1}$ and MBC values ranged between $60-12 \mu \mathrm{g} \mathrm{mL}^{-1}$ (Table 3). This value is however, higher than MIC values ranged between $0.391-25 \mu \mathrm{g} \mathrm{mL}^{-1}$ reported for leaves and bark extract of E. camaldulensis. This broad-spectrum antibacterial activities of $E$. camaldulensis may be attributed to the presence of several secondary metabolite like saponins, tannins and flavonoids. Which, were mentioned in several studies to possess antibacterial properties [46, 47]. Many other members of the genus Eucalyptus including E. viminalis, $E$. tereticornis, E. maculata and E. globulus have also been reported for antimicrobial properties [47, 48, 49].

There are many reports that support the use of antioxidant supplement in reducing the level of oxidative stress and in preventing the development of complication associated with disease [36, 22]. In this study the methanol leaves extract of Eucalyptus calmaldulensis exhibited antioxidant property as confirmed by DPPH antioxidant assay. The DPPH 
radicals were widely used to investigate the scavenging activity of some natural compounds. The extract was also found to have a high antioxidant property as confirmed by $\mathrm{Fe}^{3+}$ reducing power, The extract exhibited FRAP activities that increase with increase extract concentrations (figure 2). In DPPH scavenging assay The $\mathrm{IC}_{50}$ of the of the extract against $\mathrm{DPPH}$ radicals is $244.98 \pm 5.24 \mu \mathrm{g} / \mathrm{mL}$ as compared with 79.64 $\pm 3.78 \mu \mathrm{g} / \mathrm{mL}$ recorded for the reference drug (Ascorbic Acid). The $\mathrm{IC}_{50}$ reported in this study was lower than $\mathrm{IC}_{50}$ value of 1562.52 and 155.17 reported for $C$. adansonii and $N$. laevis [23], 52.45 $\pm 3.05 \mu \mathrm{g} / \mathrm{mL}$ reported for Xylopia aethiopica extract [26].

Serum biochemical parameters have been widely used as an indicator of pathological condition, toxicology or safety of a test substance, treatment outcome and general health status of animals [26, 22, 50]. Among these biochemical parameters, transaminases, alkaline phosphatases, proteins, albumin, bilirubins, urea creatinine and electrolyte are the most widely employed in assessing the integrity of liver and kidney following plant extract administration to animals [51]. Alterations in the normal activities or concentrations of these biochemical parameters are conventional indicators of any of the following conditions; renal or nephrotic impairments, hepatocellular injury, cellular leakage, loss of functional integrity of cell membrane, biliary cirrhosis or liver hepatitis [52]. Consequently, the concentrations of albumins, bilirubins sodium, potassium, creatinine, serum aspartate transaminase, alanine transaminase and alkaline phosphatase (ALP) activities were not significantly $(\mathrm{p}<0.05)$ altered by treatment with 250 and $500 \mathrm{mg} / \mathrm{kg}$ bw E. camadulensis. This is an indication that the functional integrity of liver is well preserved and that the extract does not induced any form of pathological conditions to the liver.

The increases in chloride concentration in rats dosed 250 and $500 \mathrm{mg} / \mathrm{kg}$ bw E. camadulensis is an indication that the integrity of the kidney as regards to this metabolite has been compromised leading to increases production or decrease tubular excretion. Similarly, the observed increase in urea concentrations could be attributed to increase in protein catabolism which resulted in the decrease serum total proteins (Table 4). The extract might have interfered with the equilibrium in protein metabolism infavor of catabolism. Such drastic decrease in protein levels could, negatively affect cellular homeostasis and consequently affect the health of the animals.

\section{CONCLUSION}

This study has shown that the methanol leaf extract of Eucalyptus calmaldulensis contains some useful potential bioactive principles that are inhibitory to some pathogenic organism as well as possess significant antioxidants properties. Thus, it may be considered as a natural source of antimicrobials and antioxidants for therapeutic purposes.

\section{Ethical approval}

The principles governing the use of laboratory animals as laid out by the Federal University of Technology, Minna Committee on Ethics for Medical and Scientific Research and also existing internationally accepted principles for laboratory animal use and care as contained in the Canadian Council on Animal Care Guidelines and Protocol Review were duly observed.

\section{Author's contributions}

This work is a collaboration of all the authors. All authors read and approved the final manuscript

\section{Consent for publication \\ Not applicable}

\section{Competing interests}

The authors declare that they have no competing interests.

\section{REFERENCES}

1. Saad, A.M., Mohammed, M.M.D., Ghareeb, M.A., Ahmed, W.S., Farid, M.A. (2017). Chemical composition and antimicrobial activity of the essential oil of the leaves of Cupressus macrocarpa Hartweg. Ex Gordon. J Appl Pharm Sci, 7:207-212

2. Lawal, B., Shittu, O.K., Ossai, P.C., Abubakar, A.N., and Ibrahim, A.M. (2015). Antioxidant Activities of Giant African Snail (Achachatina maginata) Haemolymph against $\mathrm{CCl}_{4^{-}}$Induced Hepatotoxicity in Albino Rats. British journal of pharmaceutical research, 6(3): 141-154

3. Gutteridge, J.M.C., Wilkins, S. (1986). Copper salt dependent hydroxyl radical formation. Damage to proteins acting as antioxidants. Biochem Biophys Acta, 754:38-41.

4. Lawal, B., Shittu, O.K., Oibiokpa, FI, Berinyuy, E.B., Muhammed, H. (2017). African natural products with potential antioxidants and hepatoprotectives properties: a review, Clinical Phytoscience, 2:23, 1-66 https://doi.org/10.1186/s40816-016-0037-0

5. Ghareeb, M., Saad, A., Ahmed, W., Refahy, L., Nasr, S. (2018). HPLC-DAD-ESI-MS/MS characterization of bioactive secondary metabolites from Strelitzia nicolai leaf extracts and their antioxidant and anticancer activities in vitro. Pharm Res, 10(4):xx-xx

6. Sobeh, M., Mahmoud, M.F., Hasan, R.A., Abdelfattah, M.A., Sabry, O.M., Ghareeb, M.A., El-Shazly, A.M., Wink, M. (2018). Tannin-rich extracts from Lannea stuhlmannii and Lannea humilis (Anacardiaceae) exhibit hepatoprotective activities in vivo via enhancement of the antiapoptotic protein Bcl-2. Sci Rep, 8:9343

7. Ghareeb, M.A, Refahy, L.A., Saad, A.M., Osman, N.S., Abdel-Aziz, M.S., El-Shazly, M.A., Mohamed, A.S. (2015). In vitro antimicrobial 
activity of five Egyptian plant species. J Appl Pharm Sci. 5:45-49

8. Singab, A., Ayoub, N., Al-Sayed, E., Martiskainen, O., Sinkkonen, J., Pihlaja, K. (2011). Phenolic constituents of Eucalyptus camaldulensis Dehnh, with potential antioxidant and cytotoxic activities. Rec Nat Prod, 5:271-280

9. Elliot, R.W., \& D.L. Jones. (1986). Encyclopaedia of Australian Plants Suitable for Cultivation, 4, Lothian Press, Melbourne.

10. Azzah, I.A., \& Ibtisam M. A. (2019). Phytochemical Screening and Antibacterial Activity of Eucalyptus camaldulensis's Leaves and Bark Extracts. Asian Journal of Scientific Research, 12: 202-210.

11. Meshkani, N., Naghsh, N., Ranjbar, M. (2014). Study of cytotoxic effects of ethanolic extract of Eucalyptus camaldulensis leaf on the cells k562 of human chronic Myelogenous leukemia (CML) under in vitro conditions. Bull Environ Pharmacol Life Sci, 3:186-190

12. Ghalem, B.R., Mohamed, B. (2008). Antibacterial activity of leaf essential oils of Eucalyptus globulus and Eucalyptus camaldulensis. Afr J Pharmacy Pharmacol, 2:211-215

13. Medhi, S.M., Reza, S., Mahnaz, K., Reza, A.M., Abbas, H., Fatemeh, M., Hassan, V. (2010). Phytochemistry and larvicidal activity of Eucalyptus camaldulensis against malaria vector, Anopheles stephensi. Asian Pacif J Trop Med, 3:841-845

14. Falahati, M., Omidi, Tabrizib, N., Jahaniani, F. (2005). Anti-dermatophyte activities of Eucalyptus camaldulensis in comparison with Griseofulvin. Iranian J Pharmacol Therap, 4:80-83

15. Siddiqui, B.S, Begum, S., Siddiqui, S. (1997). Isolation and structural elucidation of acylated pentacyclic triterpenoids from the leaves of Eucalyptus camaldulensis var. obtusa. Planta Med 63:47-50

16. Begum, S., Sultana, I., Siddiqui, B.S., Shaheen, F., Gilani, A.H. (2002). Structure and spasmolytic activity of eucalyptanoic acid from Eucalyptus camaldulensis var. obtusa and synthesis of its active derivative from oleanolic acid. J Nat Prod, 65:1939-1941

17. Gakuubi, M.M. (2016). Steam distillation extraction and chemical composition of essential oils of Toddalia asiatica L. and Eucalyptus camaldulensis Dehnh. J Pharmacog Phytochem 5:99

18. Harborne, J. B. (1973). Phytochemical Methods; A guild to morden Techniques to plant anaylsisSofowora A. E. (1993). Medicinal Plants and Traditional Medicine in Africa; John Wiley and Sons, Ltd, Ife, Nigeria.

19. Sofowora, A. E. (1993). Medicinal Plants and Traditional Medicine in Africa; John Wiley and Sons, Ltd, Ife, Nigeria.
20. AOAC. (1999). Official Methods of Analysis. 13th Edition, Association of Official Analytical Chemists. Washington, D.C., 768-800.

21. Gaherwal, S., Johar, F., Wast, N., Prakash, M.M. (2014). Anti-bacterial activ- ities of Allium sativum against Escherichia coli, Salmonella Ser. Typhi and Staphylococcus aureus. Int J Microbiol Res, 5(1): 19-22.

22. Tsado, N.A., Lawal, B. Kontagora, G.N., Muhammad, B.M., Yahaya, M.A., Gboke, J.A. Muhammad, U.A., Hassan, M.K. (2016b). Antioxidants and Antimicrobial- Activities of Methanol Leaf Extract of Senna occidentalis. Journal of Advances in Medical and Pharmaceutical Sciences, 8(2): 1-7.

23. Tsado A. N., Lawal B., Ossai P. C., Jagaba A., Gwadabe N. K., Jiya A. G., Umar A. M. and Oladunjoye J. O. (2016a). Antioxidants and Antimicrobial Activities of Methanol Extract of Newbouldia laevis and Crateva adansonii. Journal of Pharmacy and Allied Health Sciences, 6: 14-19. https://scialert.net/fulltext/?doi=jpahs.2016.14.19

24. Amos, T.N., Bashir, L., Saba, S.E, Saba, M.A., Mohammed, B.M., Abdulsalam, I.H. (2015). Phytochemicals and acute toxicity profile of aqueous and methanolic extracts of Crateva adansonii leaves in Swiss albino rats. Asian $\mathrm{J}$ Biochem, 10(4): 173-9

25. Shittu, O.K., Lawal, B., Alozieuwa, B.U., Haruna, G.M., Abubakar, A.N., Berinyuy, E.B.(2015). Alteration in biochemical indices following chronic administration of methanolic extract of Nigeria bee propolis in Wister rats. Asian Pac J Trop Dis, 5(8): 654-7.

26. Yusuf, A.A., Lawal, B., Abubakar, A.N., Berinyuy, E.B., Omonije, Y.O., Umar, S.I., Shebe, M.N., and Alhaji, Y.M. (2018a). In-vitro antioxidants, antimicrobial and toxicological evaluation of Nigerian Zingiber officinale. Clinical Phytoscience, 4, 12, 1-8

27. Reitman, S., Frankel, S. (1957). A colorimetric method for the determination of serum glutamic oxalacetic and glutamic pyruvic transaminases. Am J Clin Pathol, 28: 56-63.

28. Gornall, A.C., Bardawill, C.J., David, M.M.(1949). Determination of serum protein by means of biuret reaction. J Biol Chem, 177: 751-66.

29. Doumas, B.T., Watson, W.A., Biggs, H.G. (1971). Albumin standards and the measurement of serum album with bromocresol green. Clin Chem Acta 1971; 31: 87-96.

30. Blass, K.G., Thierbert, R.J., Lam, L.K. (1974). A study of the mechanism of the Jaff'e reaction. Z Klin Chem Klin Biochem, 12: 336-43.

31. Tietz, N.W.(1995). Clinical guide to laboratory tests. 3rd ed. Philadelphia, PA: WB Saunders Company, 286-8.

32. Yalta, A.T. (2008). The accuracy of statistical distributions in Microsoft ${ }^{\circledR}$ excel 2007. Comput Stat Data Anal, 52: 4579-86. 
33. Funatogawa, K., Hayashi, S., Shimomura, H., Yoshida, T., Hatano, T., Ito, H., Hirai, Y. (2004). Antibacterial activity of hydrolyzable tannins derived from medicinal plants against Helicobacter pylori. Microbiol Immunol, 48:251-261

34. Ayepola, O.O., \& B.A. Adeniyi (2008). The antibacterial activity of leaf extracts of Eucalyptus camaldulensis (Myrtaceae). J. Applied Sci. Res. 4: 1410-1413.

35. Buzzini, P., Arapitsas, P., Goretti, M., Branda, E., Turchetti, B., Pinelli, P., \& Romani, A. (2008). Antimicrobial and antiviral activity of hydrolysable tannins. Mini reviews in medicinal chemistry, 8(12), 1179-1187.

36. Ibrahim, A.M., Lawal, B., Abubakar, A.N., Tsado, N.A., Kontagora, G.N., Gboke, G.A., Berinyuy, E.B. (2017). Antimicrobial and Free Radical Scavenging Potentials of $N$-Hexane and Ethyl Acetate Fractions of Phyllanthus Fraternus. Nigerian Journal of Basic and Applied Science, 25(2): 06-11. DOI: http://dx.doi.org/10.4314/njbas.v25i2.2

37. Okwu, D. E., \& Okwu, M.E. (2004). Chemical composition of SpondiasmombinLinn. Plantparts. Journalof Sustainable Agriculture and Environment, 6(2):140-147

38. Trease, G.E. \& Evans, W.C. (1989). Pharmacognosy 11th ed. BrailliarTridel and Macmillian Publishers, London, pp. 48-65

39. Ghosal, S. Krishna-Prasad, B. N., \& Laksmi, V. (1996). Anti-amoebic activity of Piper longum fruits against Entamoebahistolytical in vivo. Journal of Ethno-pharmacology, 50:167-170.

40. Kaur, P., Singh, B., Kumar, S., Kaur, S. (2008). In vitro evaluation of free radical scavenging activity of Rubia cordifolia L. J. Chinese Clinic. Med, 3(5):278-284.

41. Lawal, B., Ossai P. C., Shittu O.K. and Abubakar, A.N. (2014). Evaluation of Phytochemicals, Proximate, Minerals and Anti-Nutritional Compositions of Yam Peel, Maize Chaff and Bean Coat. International Journal of Applied Biological Research, 6(2):01-17

42. Abubakar, E.M.M., 2010. Antibacterial potential of crude leaf extracts of Eucalyptus camaldulensis against some pathogenic bacteria. Afr. J. Plant Sci., 4: 202-209.

43. Babayi, H., I. Kolo, J.I. Okogun., \& U.J.J. Ijah, 2004. The antmicrobial activities of methanolic extracts of Eucalyptus camadulensis and Terminalia catappa against some pathogenic icroorganisms. Biokemistri, 16: 106-111.

44. Ibrahim, I.S., M. Ali., \& A.U. Zage. (2016). Phytochemistry of methanolic and aqueous extracts of Eucalyptus camaldulensis leaves, seeds and stem back. Int. J. Adv. Acad. Res. 2: 75-80
45. Yusuf, A.A., Lawal, B., Yusuf, M.A., Omonije, Y.O., Adejoke, A.A., Raji, F.H., Wenawo, D.L. (2018b).Free Radical Scavenging, Antimicrobial Activities and Effect of Sub-Acute Exposure to Nigerian Xylopia Aethiopica Seed Extract On Liver and Kidney Functional Indices of Albino Rat. Iranian journal of toxicology, 12(3): 51-58

46. Akiyama, H., K. Fujii, O. Yamasaki, T. Oono., \& K. Iwatsuki. (2001). Antibacterial action of several tannins against Staphylococcus aureus. J. Antimicrob. Chemother, 48: 487-491.

47. Dzoyem, J.P., H. Hamamoto, B. Ngameni, B.T. Ngadjui and K. Sekimizu, 2013. Antimicrobial action mechanism of flavonoids from Dorstenia species. Drug Discov. Ther., 7: 66-72

48. Bachir, R.G., \& M. Benali, 2012. Antibacterial activity of the essential oils from the leaves of Eucalyptus globulus against Escherichia coli and Staphylococcus aureus. Asian Pac. J. Trop. Biomed., 2: 739-742.

49. Dhakad, A.K., V.V. Pandey, S. Beg, J.M. Rawat and A. Singh, 2018. Biological, medicinal and toxicological significance of Eucalyptus leaf essential oil: A review. J. Sci. Food Agric., 98: 833-848

50. Shittu, O.K., Lawal, B., Abubakar, N.A., Berinyuy, B.E., Busari, M.B., Ibrahim, A.O. (2015b).

Toxicological Implications of Methanol Extract from Nigerian Bee Propolis on Some Selected Rat Tissues. Journal of Pharmaceutical and Biomedical Science, 05(06):499-506.

www.jpbms.info/index.php?option=com_docman\& task=doc_details\&gid

51. Bashir, L. Shittu O.K, Busari M.B, Sani, S., \& Aisha M.I. (2015).Safety Evaluation of Giant African land Snails (Archachatinamarginata) Haemolymph on Hematological and Biochemical Parameters of Albino Rats. Journal of Advances in medical and Pharmaceutical Sciences. 3(3):122130

52. Umar, S.I., Ndako, M., Jigam, A.A. Adefolalu, S.F., Ibikunle, G.F., \& Lawal, B. (2019). Antiplasmodial, Anti-inflammatory, antinociceptive and safety profile of Maytenus senegalensis root bark extract on hepato-renal integrity in experimental animals. Comp Clin Pathol.

53. Pulido, R., Bravo, L., Saura-Calixto, F. (2000). Antioxidant activity of dietary polyphenols as determined by a modified ferric reducing/antioxidant power assay. J. Agric Food Chem, 48:3396-3402.

54. Lawal, B., Shittu, O.K. Oibiokpa, I.F., Mohammed H, Umar, S.I., Haruna, G.M. (2016). Antimicrobial evaluation, acute and sub-acute toxicity studies of Allium sativum, Journal of Acute Disease, 5(4): 296-301. 